\title{
Microflora Formation in Newborns Depending on the Mother Microbiological Profile and Locality Altitude
}

\author{
Bibigul Orunbaeva1, Kursantbek Attokurov², Gulmira Attokurova ${ }^{3}$, Zhypargul Abdullaeva ${ }^{*}$ (i), \\ Feruza Aytieva $^{5}$, Dilfuza Tuychieva ${ }^{6}$ \\ ${ }^{1}$ Department of General Medical Disciplines, College of Medicine, Osh State University, Osh, Kyrgyzstan \\ ${ }^{2}$ Department of Natural and Fundamental Sciences, Osh State University, Medical College, Osh, Kyrgyzstan \\ ${ }^{3}$ Department of Internal Diseases, Medical Faculty, Osh State University, Osh, Kyrgyzstan \\ ${ }^{4}$ Anatomy, Histology and Normal Physiology Department, International Medical Faculty, Osh State University, Jolon Mamytov \\ Campus, Osh, Kyrgyzstan \\ ${ }^{5}$ Department of Natural Sciences and Mathematics, International Medical Faculty, Osh State University, Osh, Kyrgyzstan \\ ${ }^{6}$ Department of Zoology and Biochemistry, Andijan State University, Andijan, Uzbekistan \\ Email: *jypar.science@oshsu.kg
}

How to cite this paper: Orunbaeva, B., Attokurov, K., Attokurova, G., Abdullaeva, Z., Aytieva, F. and Tuychieva, D. (2020) Microflora Formation in Newborns Depending on the Mother Microbiological Profile and Locality Altitude. Open Journal of Medical Microbiology, 10, 162-169. https://doi.org/10.4236/ojmm.2020.103014

Received: August 14, 2020

Accepted: September 15, 2020

Published: September 18, 2020

Copyright $\odot 2020$ by author(s) and Scientific Research Publishing Inc. This work is licensed under the Creative Commons Attribution International License (CC BY 4.0).

http://creativecommons.org/licenses/by/4.0/ Open Access

\begin{abstract}
Aims: This work is aimed to investigate microflora formation, quantitative and qualitative features of various bacteria colonization in the women in labor, and newborns depending on the microbiological profile and locality altitude. Rationale: Physiological and social adaptation of newborns in extreme climate of mountains, in particular the microflora formation in unusual conditions studied. Findings: In the study of nasal microflora, the $C$. albicans species in case of women in labor were $77.7 \%$, while in the newborns $C$. albicans species were 2 times less. In lowlands, the $S$. aureus type was prevailed, while in case of midlands prevailed bacterium was $S$. epidermidis. In the newborns of highlands, $E$. coli was prevailed, as in the examined lowlands, it found as $75 \%$. In the women in labor, $C$. albicans were detected as $56.6 \%, C$. krusei was $36.6 \%, S$. aureus was $23.3 \%$, S. epidermidis was $60 \%$ and E. coli was $30 \%$. In newborns, representatives of candida fungi found: $C$. albicans was $3.3 \%$, C. krusei was $26.6 \%, S$. aureus was $43.3 \%$, S. epidermidis was $53.6 \%$ and $E$. coli was $36.6 \%$. Conclusions: In this work, we determined bacterial microflora colonization in throat, nasal, vaginal, urinoculture and skin swab of women in labor and newborns in lowland, midland and highland conditions, respectively.
\end{abstract}

\section{Keywords}

Microflora, Woman in Labor, Newborns, Microbiological Profile, Bacteria 


\section{Introduction}

Microflora formation in newborns has potential to influence and impact the physical and neurocognitive development; numerous species and strains of bacteria exist in the neonatal microbiota [1] [2]. According to the UN Commission on Sustainable Development, the well-being of half of humanity in the XXI century related to the quality of development and development of mountainous territories [3]. As it is known, the species composition of human microflora is constantly changing, and its stability is considered as a relative due to alterations caused by bacterial infections [4], pharmacodynamic and pharmacokinetic of selected antibiotics [5], lifestyle and the dietary alterations inducing temporary microbial shifts within one day [6] [7]. Newborns early life immune system is not stable. It is rapidly adapting to environmental conditions and interventions aimed to protect organism against various pathogens and disorders [8] as represented in Figure 1. Conditions for initial microbiota colonization in infants are resulting in a symbiotic relationship between the colonizing bacteria and intestinal epithelial with lymphoid tissues [9] as represented in Table 1.

\section{Research Methods}

Studies conducted in various heights in the southern region of Kyrgyzstan, under examination of 133 women in labor aged from 17 to 43 years old, and 133 newborns. Examined people divided into three groups according to the locality altitude in which they are living:

1) Residents of the lowlands, Kurshab at $1012 \mathrm{~m}$ above the sea level;

2) The inhabitants of the middle mountains, Zhalpak-Tash at $2000-2500 \mathrm{~m}$ above the sea level;

3) The inhabitants of the highlands Sary-Tash, at $3325 \mathrm{~m}$ above the sea level.

Table 1. Phases of intestinal colonization of the infant intestine.

\begin{tabular}{|c|c|}
\hline \multirow[b]{2}{*}{ Phase one } & Intrauterine period \\
\hline & $\begin{array}{l}\text { The fetus becomes exposed to maternal microbiota through transplacenta passage } \\
\text { into amniotic fluid }\end{array}$ \\
\hline \multirow[b]{2}{*}{ Phase two } & $1^{\text {st }}$ week of life \\
\hline & $\begin{array}{l}\text { The newborn ingests maternal vaginal/colonic microbiota with passage through the } \\
\text { birth canal (full term, vaginal delivery) }\end{array}$ \\
\hline \multirow{2}{*}{ Phase three } & Two weeks to four months \\
\hline & Introduction of oral liquid feedings \\
\hline \multirow{2}{*}{ Phase four } & Four months to one year \\
\hline & Period of weaning to solid foods \\
\hline \multirow[b]{2}{*}{ Phase five } & One to three years \\
\hline & $\begin{array}{l}\text { Infant receives table food and intestinal microbiome resembles that of adult } \\
\text { intestine (diversity of bacteria with greater than } 1000 \text { species) }\end{array}$ \\
\hline
\end{tabular}




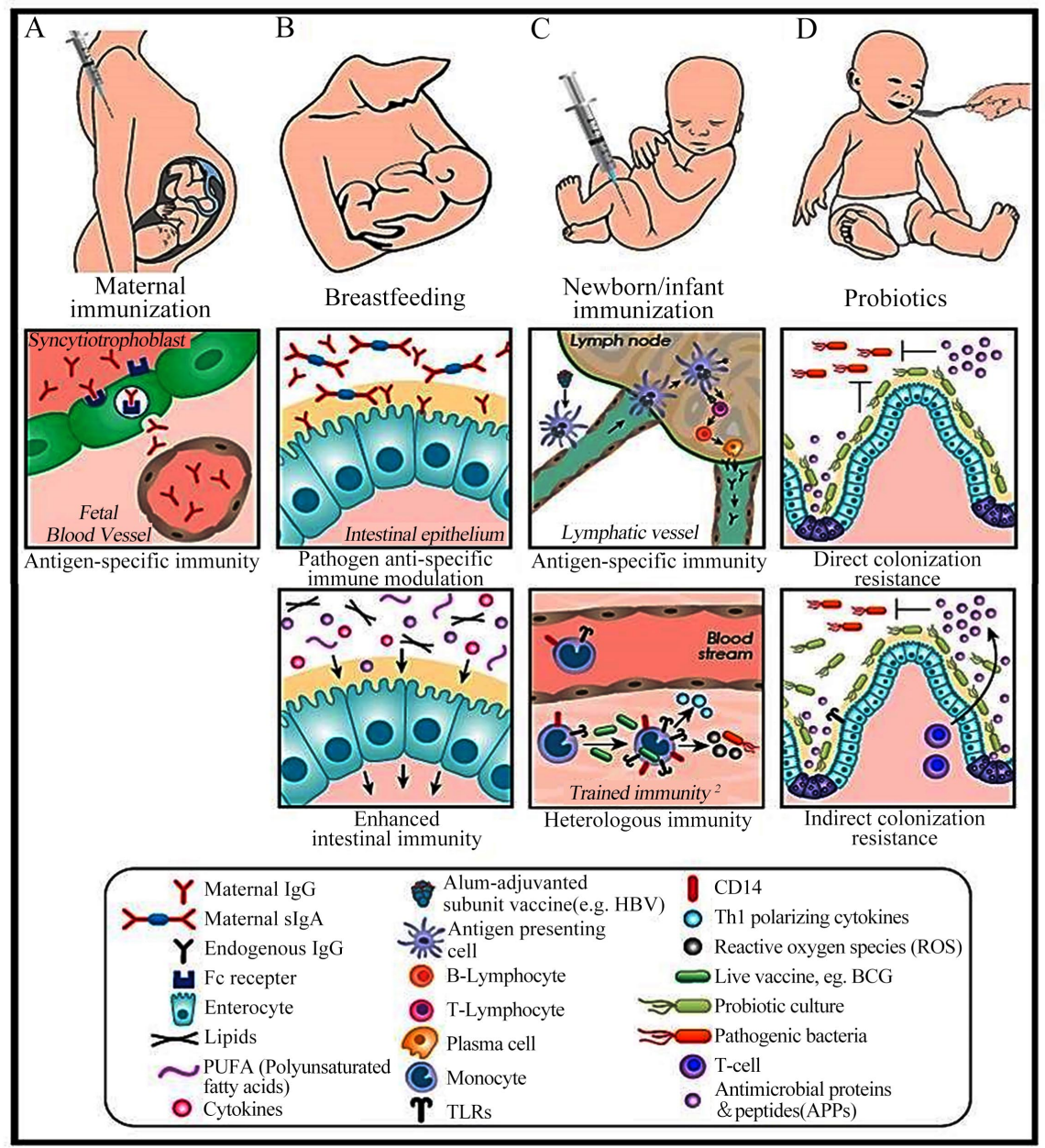

Figure 1. Interventions that Broadly Enhance Host Defense against Infectious Disease in Early Life There are key windows of opportunity during prenatal life and early postnatal life to enhance host resistance to specific infections via homologous i.e., pathogen and thus classic antigen specific responses (top panels)-as well as broadly protective heterologous ("non-specific") responses (bottom panels). (A) Maternal immunization leverages passive transfer of maternal IgG antibodies across the placenta that can protect the fetus and newborn. The specificity of the maternal IgG reflects past maternal exposures thereby targeting specific pathogens. (B) Top panel shows that breastfeeding provides secretory IgA, with specificities reflecting maternal microbiota, transferred across the gut along with maternal IgG bound to antigen; whereas the bottom panel shows that breastmilk also contains soluble factors, including cytokines, lipids, and fatty acids, that broadly enhance mucosal resistance to infection. (C) Early life immunization of the newborn or young infant reduces risk for infection with (C-top) specifically-targeted pathogens; (C-bottom) live attenuated vaccines such as Bacille Calmette Gue'rin (BCG) provide broader heterologous ("non-specific") protection, possibly via "trained immunity" mediated by epigenetic reprograming of monocytes. (D) Probiotics reduce infection. Mechanisms underlying probiotic effects remain under study and may include, for example, (D-top panel) enhancement of colonization resistance wherein bacteriocin production by probiotic bacteria targets specific pathogens without affecting commensal flora, and (D-bottom) mucosal PRR signaling-mediated enhancement of immune development, including intestinal epithelial cell expression of antimicrobial protein and peptide (APPs) as well as innate lymphoid cells and mucosal Th17 and Treg development (reprinted with permission of Elsevier) [8]. 
Healthy women in labor and newborns considered according to the inclusion criteria. Studies conducted all year round. Our purpose was to determine quantitative and qualitative values of various bacterial growth and colonization in the healthy women in labor and newborns microscopically. Variables were excluded in this research. Bacteriological studies carried out in accordance with the Order of the Ministry of Health of the Kyrgyz Republic No. 4 from January 11.2010.11, "Methodological instructions for bacteriological methods of laboratory research of clinical material". Work carried out at the Laboratory of Microbiology, Immunology and Virology of the Institute of Medical Problems of the Southern Branch of the National Academy of Sciences of the Kyrgyz Republic.

Microbiological methods such as isolation of bacteria, method of culture and identification of microbiota applied in this study. Types of samples: throat and skin swabs, nasal mucus, urine culture tested for microflora content.

\section{Results and Discussions}

In this study the throat microflora of women in labor and newborns in lowland conditions examined, during which the $C$. albicans bacteria [10] [11] detected in $19.4 \%$ mothers and in $6.9 \%$ of newborns, respectively (Figure 2). In the midland and highland conditions, this microflora was not found in the pharynx. In pharynx microflora of women in labor and newborns, C. krusei [12] bacteria observed only in lowland conditions. In the midland and highland, C. albicans bacteria not detected. $S$. aureus [13] found in all three studied groups: in lowlands, it was $8.4 \%$ in women in labor and $5.5 \%$ in newborns. In midland conditions, the $S$. aureus bacteria found as $23.3 \%$ in women in labor, and in newborns, it was $20 \%$, which is $17.3 \%$ and $26.6 \%$ higher than in the lowland group. In highlands of women in labor, $S$. aureus noted as $35.4 \%$ of cases and in $25.8 \%$ in newborns, which is almost 3 times more in comparison with the lowland group.

In the study of nasal microflora (Figure 3 ), we found the $C$. albicans species in case of women in labor were $77.7 \%$, while in newborns $C$. albicans species were 2 times less. In women of the midlands, this indicator reduced and amounted to $53 \%$, while in newborns it found only in $13 \%$ of cases, which was amounted to $34.6 \%$ in relation to the lowlandgroup. In women of the alpine group, this indicator was $45 \%$, while in newborns the C. albicans bacteria not found. C. krusei bacteria found in the women in labor in low and middle mountain conditions noted as almost $40 \%$ of cases, in newborns two times less. Figure 3 is showing microflora of nose in highland conditions, where $C$. albicans not detected in newborns. $S$. aureus bacteria in all groups were three times less in newborns comparing to the women in labor.

$S$. epidermidis bacteria dominated in the urine culture of women in labor at highlands, midlands and lowlands, as well as in newborns at lowland and highlands, at highest percentage (Figure 4). In newborns, urine culture at midlands contained dominated $S$. aureus bacteria. In the lowland conditions, in 72 women in labor C. albicans presented as $11 \%, S$. aureus was $15 \%$, and S. epidermidis was 
25\%. E. coli found 22\%, $P$. rettrgeri was $22 \%, P$. mirabilis was $31 \%$, and $P$. vulgaris was $15 \%$. In newborns urine culture $C$. albicans was detected $13 \%, S$. aureuswas $12 \%$, and $S$. epidermidis was $20 \%$, microbe species of the P. rettgeri, P. mirabilis, $P$. vulgaris and Klebsiella observed too. In the midland conditions, 30 women in labor and 30 newborns examined where from the pathogenic microflora the following bacteria species detected:

S. aureus was $40 \%, S$. epidermidis was $50 \%, C$. albicans was $9 \%-30 \%$, and $E$. coli bacteria were 15\%. In highlands, 31 women in labor and newborns examined where for women in labor the highest percentage of microflora dominated by $S$. Epidermidis species.

Skin swab microflora of women in labor and newborns analyzed for presence of bacteria. In lowlands, the $S$. aureus type was prevailed, while in case of midlands prevailed bacterium was $S$. epidermidis (Figure 5). In the newborns of highlands, E. coli was prevailed, as in the examined lowlands it found as $75 \%$. All microflora representatives in the woman in labor and in newborns were $79 \%$, in the woman in labor of midlands were $66 \%$, and in newborns were $58 \%$. In the highlands of the examined women in labor microflora bacteria were $31.1 \%$, while in newborns were $22 \%$.

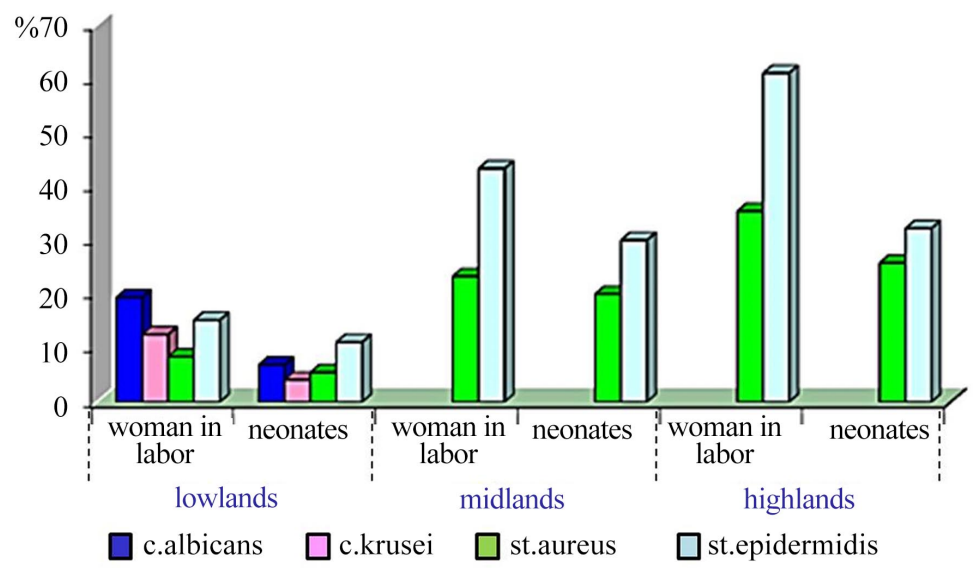

Figure 2. Microflora of the throat of women in labor and newborns.

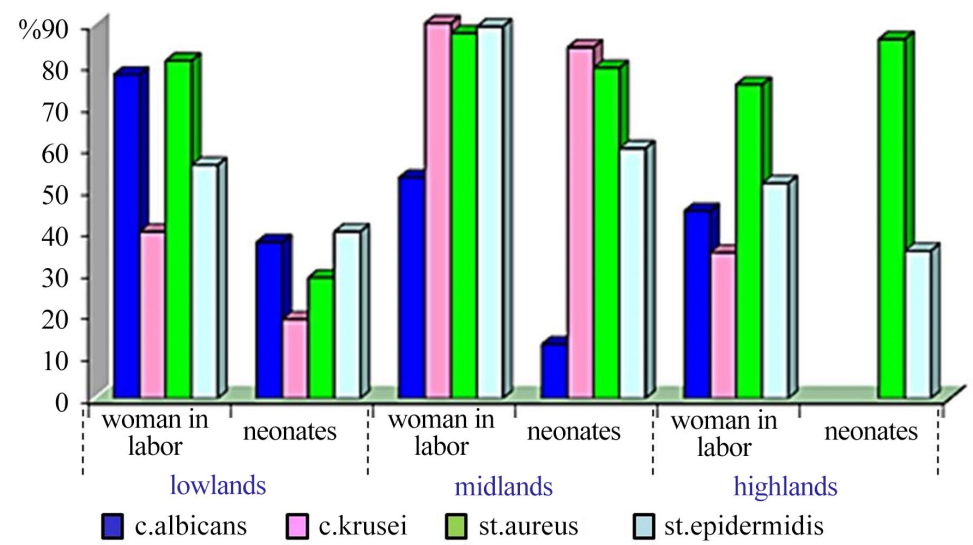

Figure 3. Microflora of the nose in women in labor and newborns. 


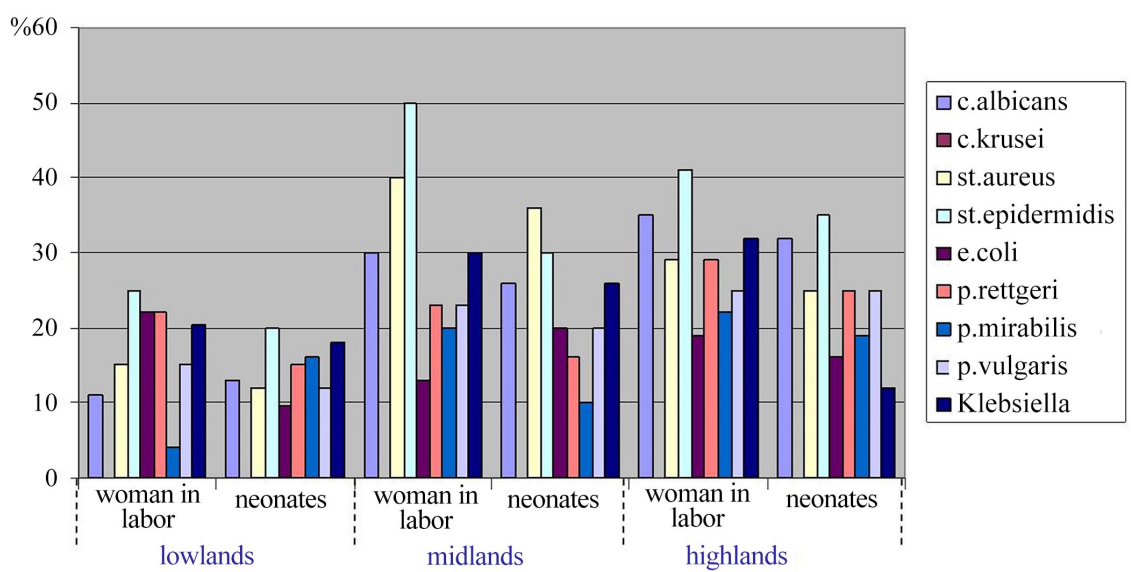

Figure 4. Microflora of the urine culture in various altitudes for woman in labor and newborns.

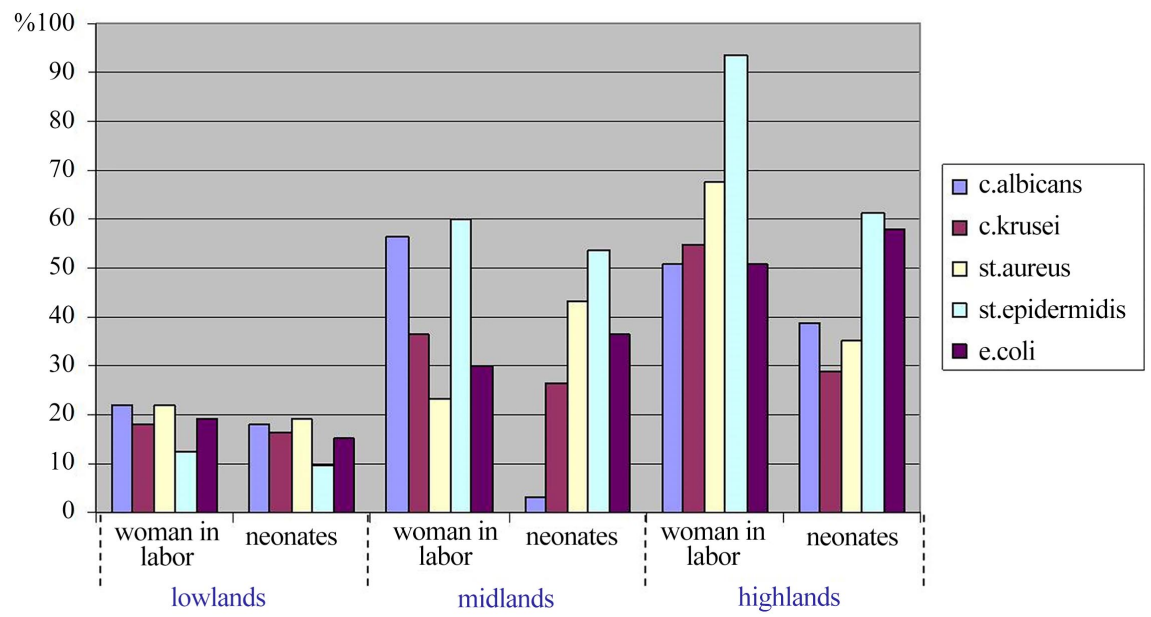

Figure 5. Skin swab microflora of woman in labor and newborns.

In the lowland conditions, skin swab microflora examination was performed for 72 women in labor, where C. albicans was $22.2 \%$, C. krusei was $18 \%, S$. aureus was $22 \%, S$. epidermidis was $12.5 \%, E$. coli was $19.4 \%$. In newborns, C. albicans found as $18.0 \%, C$. krusei was $16.6 \%$, S. aureus was $19.4 \%$, S. epidermidis was $9.7 \%$, and $E$. coli was $11 \%-15.2 \%$. As can be seen from the table, a high percentage of $S$. aureus observed for women in labor and newborns.

In the midland conditions, 30 women in labor and newborns examined. In the women in labor $C$. albicans were detected as $56.6 \%, C$. krusei was $36.6 \%, S$. aureus was $23.3 \%, S$. epidermidis was $60 \%$ and $E$. coli was $30 \%$. In newborns, representatives of candida fungi found: $C$. albicans was 3.3\%, and $C$. krusei was $26.6 \%, S$. aureus was $43.3 \%$, S. epidermidis was $53.6 \%$ and $E$. coli was $36.6 \%$. In case of highlands 31 inhabitants including woman in labor and newborns examined, where microflora of woman in labor showed C. albicans as $51 \%, C$. krusei was $54 \%, S$. aureus was $67.7 \%, S$. epidermidis was $93.5 \%$, and E. coli was $51 \%$. In the newborns $C$. albicans was $38.7 \%, C$. krusei was $29 \%, S$. aureus was $35.4 \%$, S. epidermidis was $61 \%$, and E. coli was $58 \%$. 


\section{Conclusion}

Throat examination of woman in labor and newborns in midlands and highlands showed no candida detected. In the low mountain conditions 1012 meters above sea level, a higher percentage of candida observed for women in labor, while in newborns epidermal staphylococcus dominated. Nose microflora in lowlands showed a high percentage of $C$. albicans and $S$. aureus bacteria in both mothers and newborns. In the midlands, the large number of $S$. aureus observed for women in labor, and in newborns, $S$. epidermidis found, while in the newborns of highlands, this yeast not detected. In newborns, urine culture at midlands contained dominated $S$. aureus bacteria. Skin swab microflora of women in labor and newborns analyzed for presence of bacteria. In lowlands, the $S$. aureus type was prevailed, while in case of midlands prevailed bacterium was $S$. epidermidis.

\section{Conflicts of Interest}

The authors declare no conflicts of interest regarding the publication of this paper.

\section{References}

[1] Yang, I., Corwin, E.J., Brennan, P.A., Jordan, S., Murphy, J.R. and Dunlop, A. (2016) The Infant Microbiome: Implications for Infant Health and Neurocognitive Development. Nursing Research, 65, 76-88. https://doi.org/10.1097/NNR.0000000000000133

[2] Fanaro, S., Chierici, R., Guerrini, P. and Vigi, V. (2003) Intestinal Microflora in Early Infancy: Composition and Development. Acta Pædiatrica, 92, 48-55. https://doi.org/10.1111/j.1651-2227.2003.tb00646.x

[3] Mensah, J. and Casadevall, S.R. (2019) Sustainable Development: Meaning, History, Principles, Pillars, and Implications for Human Action: Literature Review. Cogent Social Sciences, 5, 1. https://doi.org/10.1080/23311886.2019.1653531

[4] Clemente, J.C., Ursell, L.K., Parfrey, L.W. and Knight, R. (2012) The Impact of the Gut Microbiota on Human Health: An Integrative View. Cell, 148, 1258-1270. https://doi.org/10.1016/j.cell.2012.01.035

[5] Kim, S., Covington, A. and Pamer, E.G. (2017) The Intestinal Microbiota: Antibiotics, Colonization Resistance, and Enteric Pathogens. Immunological Reviews, 279, 90-105. https://doi.org/10.1111/imr.12563

[6] Rodríguez, J.M., Murphy, K., Stanton, C., Ross, R.P., Kober, O.I., Juge, N., Avershina, E., Rudi, K., Narbad, A., Jenmalm, M.C., Marchesi, J.R. and Collado, M.C. (2015) The Composition of the Gut Microbiota throughout Life, with an Emphasis on Early Life. Microbial Ecology in Health and Disease, 26, 26050. https://doi.org/10.3402/mehd.v26.26050

[7] Singh, R.K., Chang, H.W., Yan, D., Lee, K.M., Ucmak, D., Wong, K., Abrouk, M., Farahnik, B., Nakamura, M., Zhu, T.H., Bhutani, T. and Liao, W. (2017) Influence of Diet on the Gut Microbiome and Implications for Human Health. Journal of Translational Medicine, 15, 73. https://doi.org/10.1186/s12967-017-1175-y

[8] Kollmann, T.R., Kampmann, B., Mazmanian, S.K., Marchant, A. and Levy, O. (2017) Protecting the Newborn and Young Infant from Infectious Diseases: Lessons from Immune Ontogeny. Immunity, 46, 350-363.

https://doi.org/10.1016/j.immuni.2017.03.009 
[9] Walker, W.A. (2017) The Importance of Appropriate Initial Bacterial Colonization of the Intestine in Newborn, Child, and Adult Health. Pediatric Research, 82, 387-395. https://doi.org/10.1038/pr.2017.111

[10] Kim, J. and Sudbery, P. (2011) Candida albicans, a Major Human Fungal Pathogen. Journal of Microbiology, 49, 171. https://doi.org/10.1007/s12275-011-1064-7

[11] Dunn, A.B., Jordan, S., Baker, B.J. and Carlson, N.S. (2017) The Maternal Infant Microbiome: Considerations for Labor and Birth. MCN. The American Journal of Maternal Child Nursing, 42, 318-325. https://doi.org/10.1097/NMC.0000000000000373

[12] Fleischmann, J., Broeckling, C.D. and Lyons, S. (2017) Candida krusei form Mycelia along Agar Surfaces towards Each Other and Other Candida Species. BMC Microbiology, 17, 60. https://doi.org/10.1186/s12866-017-0972-Z

[13] Perez-Muñoz, M.E., Arrieta, M.C., Ramer-Tait, A.E. and Walter, J. (2017) A Critical Assessment of the "Sterile Womb" and "in Utero Colonization" Hypotheses: Implications for Research on the Pioneer Infant Microbiome. Microbiome, 5, 48. https://doi.org/10.1186/s40168-017-0268-4 